\title{
A social work study on procrastinating behavior: A case study of some Iranian high school students
}

\author{
Hadi Ansaralhosseini ${ }^{a^{*}}$, Mohammad Reza Abedi ${ }^{\text {b }}$ and Afsaneh Javadzadeh ${ }^{c}$
}

\section{H R O N I C L E}

Article history:

Received January 14, 2013

Received in revised format

18 April 2013

Accepted 20 April 2013

Available online

April 222013

Keywords:

Procrastination

Carrier development

APSS test

\section{A B S T R A C T}

\begin{abstract}
This paper presents an empirical investigation on procrastinating behavior among some high school students in city of Esfahan, Iran. The proposed study uses APSS test developed by Solomon and Rothblum (1984) [Solomon, L.J., \& Rothblum, E.D. (1984). Academic procrastination: Frequency and cognitive-behavioral correlates. Journal of Counseling, 31, 503509.]. The study selects a sample of 60 students who were enrolled as secondary high school in city of Esfahan, Iran. The study performs some intervention sessions including seven 75-minute sessions and finally post-test has been performed. The results of ANOVA test between these two groups of pre-test and post-test have revealed that the sessions could help students reduce their procrastination and increase their motivation on their education.
\end{abstract}

(C) 2013 Growing Science Ltd. All rights reserved.

\section{Introduction}

Procrastination has become a serious issue among high school students these days. Some studies forecasted that as much as $95 \%$ of college students are engaged in sort of procrastination (Ellis \& Kneus, 1977). Academic procrastination is normally defined as the self-reported tendency to put off academic tasks and experience problematic levels of anxiety related to some sort of procrastination. Therefore, self-reported procrastination constitutes more than a reasonable length of time to accomplish an assignment, but needs to include both frequent delay and remarkable anxiety (Rothblum et al., 1984). Another survey indicates that nearly one fourth of all college students' procrastinating problems are associated with academic tasks such as writing term papers, studying for exams and keeping up with weekly readings. There seems to be a positive a positive correlation between self-reported procrastination and some clinical factors such as depression, trait anxiety, etc. 
Çapan (2010) investigated the relationship among perfectionism, academic procrastination and life satisfaction of university students. They determined whether the perfectionist personality trait in university students could predict their academic procrastinations and life satisfactions and reported that self-oriented perfectionist personality trait significantly could predict academic procrastination and life satisfaction. Motie et al. (2012) investigated the role of self-regulated learning strategies as a predictor of academic procrastination and examined the relationship between gender differences in academic procrastination and self-regulated learning. Pala et al. (2011) investigated the effect of variables such as gender, department, grade level, and income on students' academic procrastinations. They study was performed among 366 students attending Faculty of Education and Faculty of Science and Letters of Celal Bayar University in Manisa, Turkey. They reported that procrastination means were various for gender groups and male students were more likely to procrastinate their academically works.

According to Hartung et al. (2008) childhood marks the dawn of vocational development, involving developmental tasks, transitions, and change. Children need to acquire the rudiments of career adaptability to envision a future, make educational as well as vocational decisions, explore self and occupations, and problem solve. Hartung et al. (2008) situated child vocational development within human life span and life course development paradigms and career development theory. They also considered the theoretical origins of career adaptability and tested it as a critical framework for construing vocational development. Two models derived from career construction theory offered guidelines for research and counseling practice designed to facilitate development through work and other social regulations.

Blanchard and Lichtenberg (2003) examined Gottfredson's revised theory of circumscription and compromise. They predicted that individuals engaging in a low degree of compromise would place the greatest importance on interests followed by prestige, and gender. In a moderate degree of compromise situation, the survey suggested that individuals would place the greatest importance on prestige followed by interests, and gender. According to Carette et al. (2013) to avoid the potential threats of career plateauing for mid-career employees, it is better to give them challenging assignments. This technique is inspired by empirical findings specifying that challenging job assignments generally influence positively on job performance and career development. However, these studies have predominantly investigated the performance impacts of job challenge for employees who were in their early career.

Carette et al. (2013) argued that the relationship between challenging assignments and in-role job performance could depend on when people encounter them in their career. In their survey, for earlycareer employees, a positive relationship appeared between having challenging assignments and peerrated in-role job performance. For mid-career employees, the relationship demonstrated an inverted U-shaped curve, such that challenging assignments had a positive impact on in-role job performance up to some point and then begin to exhibit diminishing returns. Their findings recommended that challenging assignments could be tailored to the experiential background of the employee.

Gamboa et al. (2013) clarified the relationship between work experience quality and students' vocational development. They reported that the quality of work experience was relevant for the vocational development of students.

\section{The proposed study}

The proposed study of this paper uses a semi-experimental survey in terms of pre-test, post-test and control. In this study, we first use APSS test developed by Solomon and Rothblum (1984) among a group of 60 students who were enrolled as secondary high school in city of Esfahan, Iran. Next, the study performs some intervention sessions including seven 75-minute sessions and finally post-test has been performed. The study analyzes two groups of pre-test and control using SPSS software 
package using descriptive statistics including mean, standard deviation as well as ANOVA test. Table 1 shows details of currier path compatibility.

Table 1

The summary of carrier path compatibility

\begin{tabular}{|c|c|c|}
\hline Session & Title of session & Summary of session \\
\hline First & $\begin{array}{l}\text { Building appropriate } \\
\text { communication and } \\
\text { preparation }\end{array}$ & $\begin{array}{l}\text { In this session, consultant introduce him/herself and presents an } \\
\text { overview on educational negligence procedure }\end{array}$ \\
\hline Second & Concerns & $\begin{array}{l}\text { A future-oriented look using news release, highlighting } \\
\text { individual's role by reminding his/her responsibilities, } \\
\text { discussing difference between being optimistic, pessimistic or } \\
\text { realistic }\end{array}$ \\
\hline Third & Control & $\begin{array}{l}\text { Providing some discussion on various kinds of decision-making, } \\
\text { anxiety and its management }\end{array}$ \\
\hline Fourth & $\begin{array}{l}\text { Curiosity (discovering } \\
\text { people's personality) }\end{array}$ & $\begin{array}{l}\text { Presenting Holland's theory of career choice, in this session, } \\
\text { students are requested to learn about a job and provide } \\
\text { necessary discussion }\end{array}$ \\
\hline Five & $\begin{array}{l}\text { Curiosity (Discover the world } \\
\text { of business) }\end{array}$ & $\begin{array}{l}\text { In this session, each student is given a chance to give a } 5 \text {-minite } \\
\text { long lecture on a career choice and a panel discussion is also } \\
\text { prepared to exchange feedbacks. }\end{array}$ \\
\hline Six & Trust & $\begin{array}{l}\text { In this session, students learn to become a problem-solver } \\
\text { person with trouble shooting capabilities. }\end{array}$ \\
\hline Seven & Evaluation and conclusion & $\begin{array}{l}\text { In this session, we review all the materials discussed earlier and } \\
\text { receive the necessary feedback. }\end{array}$ \\
\hline
\end{tabular}

\section{The results}

In this section, we present details of our findings on comparing some statistics on students' procrastination through a questionnaire survey. Table 2 summarizes the mean and standard deviation of educational negligence in pre-test and post-test stages,

Table 2

The results of some basic statistics on measuring the impact of educational procrastination

\begin{tabular}{lcccc}
\hline Group & Exam type & Mean & Standard deviation & Numbers \\
\hline Experiment & Pre-test & 74.63 & 14.12 & 30 \\
& Post-test & 73.67 & 13.1 & 30 \\
\hline Control & Pre-test & 74.23 & 8.29 & 30 \\
& Post-test & 74.13 & 8.11 & 30 \\
\hline
\end{tabular}

The proposed study of this paper uses Levin test to examine the variances of educational negligence for two groups. The implementation of Levin test yields $\mathrm{F}=0.51$ with 1 and 58 degrees of freedom and P-Value $=0.48$. In addition, Table 3 shows details of ANOVA test for pre-test and post-test.

\section{Table 3}

The summary of ANOVA test

\begin{tabular}{llccccc}
\hline Group & Sum of Squares & df & F-value & P-Value & Effects & Power of statistics \\
\hline Pre-test & 6554.69 & 1 & 4403.5 & 0.001 & 0.98 & 1 \\
Post-test & 50.73 & 1 & 33.1 & 0.001 & 0.36 & 1 \\
\hline
\end{tabular}

Based on the results of Table 2, F-value is equal to 33.1, which is statistically significance $(\mathrm{P}<0.001)$. The effect ratios for pre-test and post-test are equal to 0.98 and 0.36 , respectively. Therefore, we can 
conclude that the educational negligence test has improved students' motivations to care more about education and reduces students' negligence.

\section{Conclusion}

In this paper, we have presented an empirical investigation among high school students on procrastination and provided some experimental test on some groups to see whether it could be possible to reduce the impact of procrastination among these students. The survey has divided the students into three groups of pre-test, post-test and control and using ANOVA test has concluded that it could be possible to reduce the impact of procrastination.

\section{References}

Balkis, M., \& Duru, E. (2009). Prevalence of academic procrastination behavior among pre-service teachers, and its relationship with demographics and individual preferences. Journal of Theory and Practice in Education, 5(1), 18-32.

Blanchard, C.A., Lichtenberg, J. A. (2003). Compromise in career decision making: A test of Gottfredson's theory. Journal of Vocational Behavior, 62(2), 250-271.

Brown, S. D. \& Lent, R. W. (2005). Carrier development and counseling. Putting Theory and Research to work, Canada: Wiley.

Carette, B., Anseel, F., \& Lievens, F. (2013). Does career timing of challenging job assignments influence the relationship with in-role job performance?. Journal of Vocational Behavior, 83, 6167.

Çapan, B.E. (2010). Relationship among perfectionism, academic procrastination and life satisfaction of university students. Procedia - Social and Behavioral Sciences, 5, 1665-1671.

Ellis, A., \& Kneus, W.J. (1977). Overcoming Procrastination. New York: Institute for Rational Living.

Gamboa, V.,Paixão, M.P., \& de Jesus, S.N. (2013). Internship quality predicts career exploration of high school students. Journal of Vocational Behavior, 83(1), 78-87.

Hartung, P. J., Porfeli, E. J., \& Vondracek, F. W. (2008). Career adaptability in childhood. The Career Development Quarterly, 57(1), 63-74.

Motie, H., Heidari, M., Sadeghi, M.A. (2012). Predicting academic procrastination during selfregulated learning in Iranian first grade high school students. Procedia - Social and Behavioral Sciences, 69(24), 2299-2308.

Pala, A., Akyıldı, M., \& Bağcı, C. (2011). Academic Procrastination Behaviour of Pre-service Teachers' of Celal Bayar University. Procedia - Social and Behavioral Sciences, 29, 1418-1425.

Rothblum, E.D., Beswick, G., \& Mann, L. (1984). Psychological antecedents of student procrastination. Unpublished manuscript, Flinders University of South Australia, Adelaide, Australia.

Rothblum, E. D., Solomon, L. J., \& Murakami, J. (1986). Affective, cognitive, and behavioral differences between high and low procrastinators. Journal of Counseling Psychology, 33(4), 387394.

Solomon, L.J., \& Rothblum, E.D. (1984). Academic procrastination: Frequency and cognitivebehavioral correlates. Journal of Counseling, 31, 503-509. 